\title{
Contrastive Analysis of Bengali and English Articles
}

\author{
Mohammad Taher Hossain Salim¹, Mohammad Humayun Kabir ${ }^{2}$ \\ ${ }^{1}$ (Lecturer), ${ }^{2}$ (Associate Professor) \\ Department of English Language \& Literature, International Islamic University Chittagong \\ 154/A, College Road, Chittagong 4203, Bangladesh
}

\begin{abstract}
The study attempts to identify the similarities and differences in the position, function and usage of the articles in Bengali and English languages. For this purpose, it takes Contrastive Analysis (CA) to compare the two sub-systems of the languages and finds that there exist some similarities and differences in the articles in both the languages. As differences pose difficulty in the acquisition of a second language (L2), the study, therefore, discusses and recommends prospective care and necessary steps that the language teachers are required to take while teaching the articles in English.
\end{abstract}

Keyword: Contrastive Analysis, Bengali articles, English Article, Definite article, Indefinite Article

\section{Introduction}

The origin of Contrastive Analysis (CA) was pedagogic. This was found 'in comparison of several pairs of languages by scholars in the United States, all directed at establishing the areas of learning difficulty that were likely to be experienced by English Speakers learning other languages'( Ellis, 1986, p. 23). This very scientific approach of learning a target language has taken a wrong shape in the foreign language teaching pedagogy in Bangladesh. We have long observed that our language teachers consider that English (foreign Language in Bangladesh) and Bengali (first language) grammars are very much similar from their structural point of view. We may, for example, mention teachers' (mis)understanding of the structural similarity of Passivisation, Reported Speech, Sentence, Phrase, Number and Article etc. Whenever our language teachers teach a grammatical point, they translate the term in Bengali and try to establish that English grammar is the translation of Bengali Grammar or vice versa. This overgeneralization creates a big problem for the learners. They (teachers) tend not to understand that every language has its own structure, its own peculiarity and individuality. The teachers, most at school and college levels, adopt this policy to ease the foreign language (FL) learning without realizing that it makes the FL learning problematic and erroneous.

In this paper, we have tried to establish above point clearly so that the teachers may realize that there lie differences between the two language systems and sub-systems. If they are well-aware of these differences along with the similarities, they will be able to teach English to the Bengali learners more effectively and learning may become effortless.

Furthermore, we notice that our teachers insist on memorization of grammatical rules. They very often fail to realize that grammar learning is a process rather than a product. We agree with Nunan $(1988, p .35)$ when he points out that 'grammar learning should not be seen as the memorization of sets of grammatical items, but as the raising of consciousness in the learner of the ways grammatical and discourse process operate and interact in the target language'.

We believe this study will help our language teachers to adopt a scientifically pragmatic method of teaching and thus benefit the FL learners as well.

\section{Articles in English and Bengali}

Articles in English are 'the most common and typical central determiners' (Quirk, Greenbaum, Leech, \& Svartvik, 2010, p. 253) used to 'express definiteness or indefiniteness of a noun or reference' (Uddin, 2013, p. 38). In English, the and a/an respectively are known as the definite and indefinite articles (Quirk et all) and in Bengali, ektı and ektə are used as indefinite article while tr, tə, ka:nə, ka:nI, gu:lu, gu:lə etc. are used as definite articles ( Sen, 2011).

Articles are most frequently used words in English language. According to COBUILD frequency count (Sinclair 1990, p. 143), the is the most frequent used word in English language and a is the fifth most frequent. Brown's (1973) morpheme study shows that articles a and the come at number nine and ten respectively in the acquisition of fourteen morphemes.

Though almost all languages have article system, they differ from one another regarding position, function, usage etc. It varies from language to language. For example: In English, to make a reference specific only, the is used before all types of references whereas in Bengali to make a reference specific based on the 
nature of the references, a number of articles such as tI, to, ka:no, ka:nI, gu:lv, gu:lə etc. are used after the references. This is just one of the examples of the differences in both the languages.

Because of the differences in the article systems in Bengali and English, teaching the English article to the Bengali learners is always challenging as Bengali article system may interfere in the way. The study, therefore, explores the areas of difficulty in teaching and learning English articles.

Figure 1: Articles in English and Bengali Languages

\begin{tabular}{|c|c|}
\hline \multicolumn{2}{|c|}{ Articles in English and Bengali } \\
\hline English & Bengali \\
\hline \multicolumn{2}{|c|}{ Indefinite } \\
\hline $\mathrm{a} / \mathrm{an}$ & ektI/ekto \\
\hline \multicolumn{2}{|c|}{ Definite } \\
\hline the & tI, to, ka:na, ka:nI, gu:lo, gu:la \\
\hline
\end{tabular}

\section{Contrastive Analysis (CA)}

Contrastive Analysis (CA), an application to the structural linguistics to language teaching, is a system of comparing two languages in order to point out the similarities and differences in different aspects of the languages. More specifically, it is a comparison of the linguistic systems of two languages where the sound system or the grammatical system of those languages is compared. Gass and Selinker (2001) defines it as 'a way of comparing languages in order to determine potential errors for the ultimate purpose of isolating what needs to be learned and what does not need to be learned in a second language (L2) learning situation'.

CA dates back to the 1950s and 1960s. Lado, the pioneer of CA, in his influential book Linguistics Across Culture (1957) claims, 'individuals tend to transfer the forms and meanings, and the distribution of forms and meanings of their native language and culture to the foreign language and culture - both productively when attempting to speak the language and to act in the culture, and receptively when attempting to grasp and understand the language and the culture as practiced by natives' (p.2). Earlier, Fries (1945, p. 9) maintains, 'the most effective materials are those that are based upon a scientific description of the language to be learned, carefully compared with the parallel description of the native language of the learner'. According to Smith (1969), the differences that exist between the languages are problematic for non-native learners who often transfer structures acquired in speaking mother tongue into the target language.

Richards, Platt and Weber (1985, p.63) state that CA is based on the following assumptions:

i. The main difficulties in learning a new language are caused by interference from the first language.

ii. These difficulties can be predicted by Contrastive Analysis

iii. Teaching materials can make use of CA to reduce the effects of interference.

Johnson and Johnson (eds) $(1998$, p. 85$)$ state 'CA has been used as a tool in historical linguistics to establish language genealogies, in comparative linguistics to create language taxonomies and in translation theory to investigate problems of equivalence'. Widdowson (2003) rightly holds that CA 'was designed for diagnosis and prevention: it was to provide the prophylactic means whereby the learning of the L2 might, as far as possible, be protected against L1 cognition'.

\section{The scope of study}

The study is limited to simple theoretical description of two subsystems in English and Bengali articles. The study explores the problematic areas in the use of articles in English because of the interferences of the learners' knowledge of Bengali articles and offers some pedagogical implications and recommendations which may hopefully help the language teachers and learners in teaching and learning English articles with lesser L1 interference.

\section{Article System in Bengali and English}

In English a and an are used as indefinite articles and in Bengali ektı and ekto are used as indefinite articles. In English the is used as definite article and in Bengali tı,, to, ka:nə, ka:nI, gu:lv, gu:lə etc. are used as definite article. 


\section{Position of article in English and Bengali}

\subsection{Similarity in terms of position:}

i. In English, the indefinite articles occur before the reference.

a. I have bought a mobile.

b. He is an American.

In examples (a) and (b), the articles a and an are placed before the references ( mobile and American).

Similarly, in Bengali the indefinite articles occur before the reference.

c. a:mi ektı məobail fəun kinetfi

I a mobile phone have bought. (I have bought a mobile phone.)

d. ta:r ekta: putul a:fe

$\mathrm{He}$ a doll has. (He has a doll)

In examples (c) and (d) the articles ektı and ektə: are placed before the references (məobarl and putul).

\subsection{Dissimilarity in terms of position:}

i. In English, the definite article 'the' is placed before the reference.

a. I'm looking for the book that I wanted to show you.

b. The minister is to announce the programs.

In examples (a) and (b), the definite article the is placed before the references (book and minister).

But in Bengali, the definite articles occur after the reference (Chowdhury \& Chowdhury, 1983).

c. məobailta tforı ho:eətfo. (The mobile has been stolen.)

d. a:mi borgu:lo niətfi. (I have taken the books.)

In the examples (c) and (d), the definite articles to and gu:lo appear after the references (məobarl and bor)

ii. In English, no article is used when descriptive pronoun comes before the noun while in Bengali, definite article is used in the same case.

a. My Mistress' eyes nothing like the sun.

b. This man has earned name and fame.

c. a:mur məobailto tforr ho:eətfo.

My mobile (x) has been stolen. (My mobile has been stolen.)

d. tomar boigu:lo a:mi niətfi

Your books (x) I have taken. (I have taken your books.)

In examples (a) and (b), no article is used because the references (Mistress' eyes and man) are preceded by descriptive pronoun, but in the examples (c ) and (d), definite articles to and gu:lo are used after the references (məobail and boi)

\section{Discussion:}

English has only one definite article, the, which is used with both singular and plural nouns whereas Bengali has a number of definite articles. Of them, some e.g. tr,, to etc. are used only with singular nouns and some e.g. gu:Is, gu:lə etc are used only with plural nouns. Again, in Bengali the definite articles are attached to the reference but in English the definite article is used as a separate word in the sentence.

\subsection{Uses of articles in English and Bengali}

\subsubsection{Indefinite article}

i. When any reference (singular countable) is mentioned for first time in any context in English, an indefinite article is used before the reference. 
a. Adit bought a book. The book is about the life of Salauddin.

b. The City Engineers is an engineering farm. Rupa works at the farm.

Similarly, in Bengali when any reference ( singular countable) is mentioned for first time in any context an indefinite article is used before the reference.

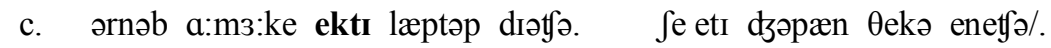

Arnob me a laptop has given. He it Japan from has brought.

( Arnob has given me a laptop. He has brought it from Japan)

d. a:mi ektı ko:ləm peətfi. ko:ləm tı k3:r.

I a pen have got. Pen ( $\mathrm{x}$ ) whose (is this)?

( I have got a pen. Whose pen is this it?)

In examples (a) and (b), English indefinite articles a and an are used before the references (book and engineering farm ) which are used for the first time. Similarly, in examples (c) and (d), Bengali indefinite article ektı is used before the references (læptəp and ko:ləm).

ii. In English, sometimes indefinite articles can be used to mean a reference wholly/ generally.

a. A tiger runs more gracefully than most animals.

b. A car became an increasing necessity of life in the twentieth century.

Similarly, in Bengali sometimes indefinite articles can be used to mean a reference wholly.

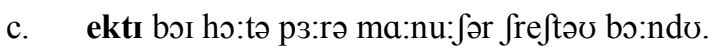

A book may be man's best friend. ( A book may be man's best friend.)

d. eI dзugə ektə məubarlər prorəuzə:nıəutə əpərifi:m.

This age a mobile's necessity no limits. (Mobile is a basic need in this age)

In the examples (a) and (b), indefinite article $\mathbf{a}$ is used to mean a references (tiger and car) in general sense and in the same way, in the examples (c) and (d), Bengali indefinite articles ektı and ekto preceded the references (bəI and məobarlər) in order to generalize the references.

\subsection{Definite article}

\subsubsection{Similarity}

In English, definite article is determined by grammatical factor (Quirk \& Greenbaum, 1973). After the first mention of any reference in any context, the successive uses of the very reference must be preceded by the definite article:

a. Akib bought a camera and a mobile, but he returned the camera.

In the same way in Bengali, after mentioning first time any reference as many times as it is mentioned in any context, definite article is used with the reference.

b. a:mı ga:tək3:1 ektə sınəmə deketfi. sınəmətI ektI ətım b3:lək kə nıə

I yesterday a film watched. Film the an orphan boy about.

(I watched a film yesterday. The film is about an orphan.)

In the example (a), when the reference (camera) is mentioned for the first time, indefinite article a is used before the reference (camera) but when the reference (camera) is repeated for the second time, definite article the is used before the reference. The same rule applies to the example (b). Indefinite article ekto is used before the reference (sinəmə), but when the reference is mentioned for the second time, definite article $\mathbf{t}$ is used with the reference. 


\subsubsection{Dissimilarity}

i. In English, definite article is used with any unique reference. Nouns premodified by superlatives, ordinals, and similar restrictive items such as sole will thus be made logically unique (Quirk \& Greenbaum, 1973):

a. The earth moves round the sun.

b. Asif is the best boy of the class.

c. When is the next flight?

d. The Chairman is the sole authority in the company.

But in Bengali, no article is used with any unique reference (Shahidullah, 2003):

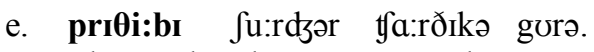

The Earth the sun round moves. ( The earth moves round the sun.)

f. $\Lambda$ sif kla:sər ferə ţəlo

Asif class of best boy. ( Asif is the best boy of the class.)

g. po:rəbərtI flait kəkən

next flight when? ( When is the next flight?)

h. $\quad \mathrm{t}$ feə(r)mən holen kompənir ekmatrə kərto.

Chairman is company sole authority ( The chairman is the sole authority of the company)

In the examples (a), definite article the is used before the unique reference (earth) while in (b), (c) and (d), the is used before the nouns premodified by the superlative (best), ordinal (next) and restrictive item (sole). But in the examples (a), (b), (c) and (d), no article is used before the references priti:bi (the earth), tfalo (boy), flart (flight) and kərtə (authority).

ii. Definite article is often used in English to make a reference generic:

a. The tiger is a ferocious animal.

But in Bengali definite article cannot be used to make a reference generic:

b. ba:g ekti hinsrəo prani:

tiger a ferocious animal ( The tiger is a ferocious animal.)

In example (a), definite article the is used before tiger in order to make the reference (tiger) generic whereas in the example (b) no article is needed to do the same.

iii. Sometimes in Bengali definiteness is marked based on human - non human referent. Some markers such as ka:n, ka:nə etc. are only used with non human referent to make the referent specific:

a. boi ka:nə a:mər

Book the mine. (The book is mine.)

But English does not at all have this type of distinction.

\section{Pedagogical Implication}

The study shows that there exist many differences in the use of articles in English and Bengali. It is an inherent nature of the learners to apply those rules to a new area /field with which they are already familiar. When these rules resemble the first language, they accelerate the learning but when they are not similar, they hinder the progress in the process of learning a second or foreign language. According to Corder (1973) when similarities exist between the first language and second language, first language helps learning second language. If language instructors are aware of the differences lying between the first language of the learners and their target language, they can easily predict where the learners may face difficulty and effectively can take necessary steps to reduce error which the learners are likely to make.

\section{Recommendations}

The study shows that there lie differences between articles of English and Bengali. So, the language teachers in Bangladesh should give special attention to designing syllabus, preparing materials and making exercises on English articles. In the class, the teacher should make his students aware of the differences where they are likely to commit error. Bengali learners, for example, may omit using definite article before unique 
reference or superlative degree as Bengali language does not require any article in such cases. So, more and more exercises, drills such as filling in the blanks, correction and multiple choice questions on English articles should be exercised in the class so that errors can be reduced.

\section{Conclusion}

That every language has its individual characteristics is a well-established issue in the field of ELT (English Language Teaching). However, Bangladeshi Language teachers tend to overgeneralise the fact when they teach English. They have a wrong notion to show similarity between Bengali and English languages when they teach grammar. This paper focuses on CA and shows that there lie differences between systems and subsystems of articles in Bengali and English languages. We assume our language teachers and students will, alike, have a clear knowledge of the challenges they have in teaching and learning the English articles and thus the study will be of a great use to both of them.

\section{References}

[1]. Ellis, R. (1986). Understanding second language acquisition. Oxford University Press

[2]. Nunan, D. (1988). Syllabus Design. Oxford University Press

[3]. Quirk, R., Greenbaum, S., Leech, G. \& Svarvik, J.(2010) A Comprehensive grammar of the English language. New York: Longman Inc.

[4]. Uddin, S.M (2013). English for Bengali Learners, A Practice Book for Bengali Speaking People.

[5]. Sen, S. (2011). Bhashar Itibritto. Kolkata: Ananda Publishers.

[6]. Sinclair, J. (1991). Corpus, concordance, collocation. Oxford: Oxford University Press.

[7]. Brown, R. (1973). Development of the first language in the human species. American Psychologist, 28, 97-106.

[8]. Gas, M. S and Selinker, S. (2001). Second Language Acquisition: An Introductory Course,

[9]. Lado, R. (1957). Linguistics across cultures: Applied linguistics for language teachers. Ann Arber: University of Michigan Press.

[10]. Fries. C. (1945). Teaching and learning English as a foreign language. Ann Arbor: University of Michigan Press

[11]. Smith, N.V. (1969). Oral English for School Certificate. J.N.E.S.A. Vol. 3

[12]. Richards, Platt \& Weber (1985). Longman dictionary of applied linguistics. Harlow, Essex, England: Longman.

[13]. Johnson,K. and Johnson,H.(eds.) (1998). Encyclopaedic Dictionary of Applied Linguistics. Blackwell Publishers Ltd.

[14]. Widdowson, H. (2003). Defining Issues in English Language Teaching. Oxford University Press.

[15]. Chowdhury, M. \& Chowdhury, H.M. (1983). Bangla Bhashar Bayakaron, NCTB, Dhaka.

[16]. Quirk, R. \& Greenbaum, S. (1973). A University Grammar of English, Longman

[17]. Shahidullah, M. (2003) Bangala Bayakaron, Dhaka: Mowla Brothers.

[18]. Corder, S. P. (1973). Introducing applied linguistics. London: Penguin Books Ltd. 